\title{
Paenibacillus sepulcri sp. nov., isolated from biodeteriorated mural paintings in the Servilia tomb
}

Correspondence

Jakub Šmerda

Jsmerda@mail.muni.cz

\author{
Jakub Šmerda, ${ }^{1} \dagger$ Ivo Sedláček, ${ }^{2}$ Zdena Páčová, ${ }^{2}$ Eva Krejči ${ }^{3}$ \\ and Ladislav Havel ${ }^{1}$
}

\author{
${ }^{1}$ Department of Plant Biology, Faculty of Agronomy, Mendel University of Agriculture and \\ Forestry in Brno, Zemědělská 1, 61300 Brno, Czech Republic \\ ${ }^{2}$ Czech Collection of Microorganisms, Faculty of Science, Masaryk University, Tvrdého 14, \\ 60200 Brno, Czech Republic \\ ${ }^{3}$ Institute of Public Health in Ostrava, Partyzánské nám. 7, 70200 Ostrava, Czech Republic
}

The genus Paenibacillus was first proposed by Ash et al. (1993) and its description was emended by Shida et al. (1997). The genus Paenibacillus is under intensive taxonomic investigation, with ten species having been formally described in the last year. Heyrman \& Swings (2001) isolated a strain, originally classified as Paenibacillus sp. LMG 19508, from biodeteriorated mural paintings in the Servilia tomb at the Roman necropolis of Carmona in Seville, Spain. Thereafter, the strain was deposited in the Czech Collection of Microorganisms as CCM 7311 and used for biodiversity studies. The phylogenetic position and characteristics of this strain were investigated using a polyphasic approach. The sequence of its 16S rRNA gene showed that the closest phylogenetic neighbour is Paenibacillus mendelii (Šmerda et al., 2005). On the basis of phylogenetic, DNA relatedness, chemotaxonomic and phenotypic analyses, we propose the classification of strain CCM $7311^{\mathrm{T}}$ as the type strain of a novel species within the genus Paenibacillus.

tPresent address: Institute of Botany and Zoology, Faculty of Science, Masaryk University, Kotlářská 2, 61137 Brno, Czech Republic.

The GenBank/EMBL/DDBJ accession number for the 16S rRNA gene sequence of strain CCM $7311^{\top}$ is DQ291142.

A extended neighbour-joining phylogenetic tree based on almostcomplete 16S rRNA gene sequences is available as a supplementary figure in IJSEM Online.
Strain CCM $7311^{\mathrm{T}}$ and the reference cultures listed in Table 1 were grown on tryptone soya agar (Oxoid) at $30^{\circ} \mathrm{C}$ to investigate their morphological and physiological characteristics. For cellular fatty acid analysis, cells were grown on trypticase soya broth (BBL) solidified with agar (Difco) at $28^{\circ} \mathrm{C}$ for $24 \mathrm{~h}$. For DNA extraction, all samples were cultivated on tryptone soya agar (Oxoid) at $30^{\circ} \mathrm{C}$ for 4 days.

Investigations of cell morphology, physiology and biochemistry were performed using the methods of Gordon et al. (1973). The method of Pácová \& Kocur (1984) was used to test for the hydrolysis of Tween 80 and gelatin, and OXItest and the HIPPURATEtest (Pliva-Lachema) were used for oxidase and hippurate hydrolysis tests. Anaerobic growth was determined in BBL anaerobic agar tubes (Becton Dickinson) according to the manufacturer's instructions. Acid production from carbohydrates was determined using API $50 \mathrm{CH}$ strips (bioMérieux), according to the manufacturer's instructions, after incubation for up to 7 days. The distinguishing phenotypic traits of strain CCM $7311^{\mathrm{T}}$ and closely related species are shown in Table 1.

Whole-cell fatty acids from the isolate and reference cultures were extracted and analysed according to the instructions in the manual for the Microbial Identification System (MIDI, 2001). The major fatty acid in strain CCM $7311^{\mathrm{T}}$ is anteiso$\mathrm{C}_{15: 0}$, which corresponds with that of members of the genus 
Table 1. Distinctive phenotypic characteristics of strain CCM $7311^{\top}$ and phylogenetically related species of Paenibacillus

Strains: 1, strain CCM $7311^{\mathrm{T}}$; 2, P. mendelii CCM 4839 ; 3, P. curdlanolyticus CCM 4536 ${ }^{\mathrm{T}}$; 4, P. glycanilyticus JCM $11221^{\mathrm{T}}$; 5, P. kobensis CCM $4537^{\mathrm{T}}$; 6, P. phyllosphaerae CCM $7310^{\mathrm{T}}$. All data are from this study unless indicated. +, Positive; -, negative; $\mathrm{W}$, weak reaction.

\begin{tabular}{|c|c|c|c|c|c|c|}
\hline Characteristic & 1 & 2 & 3 & 4 & 5 & 6 \\
\hline Anaerobic growth & - & + & - & - & - & + \\
\hline Oxidase & + & + & - & - & - & + \\
\hline Nitrate reduction & - & - & $\mathrm{W}$ & - & $-*$ & $-\dagger$ \\
\hline \multicolumn{7}{|l|}{ Hydrolysis of: } \\
\hline Starch & - & - & + & + & + & + \\
\hline Hippurate & + & - & + & + & - & - \\
\hline Urea & - & - & $-{ }^{*}$ & + & $-*$ & - \\
\hline \multicolumn{7}{|l|}{ Acid production from: } \\
\hline Glycerol & - & + & + & + & - & + \\
\hline D-Arabinose & + & + & - & - & - & - \\
\hline Ribose & - & + & - & + & - & - \\
\hline Galactose & + & + & $+^{*}$ & + & $+^{*}$ & + \\
\hline D-Fructose & - & + & + & - & + & + \\
\hline D-Mannose & + & - & $+^{*}$ & + & $+^{*}$ & + \\
\hline Rhamnose & + & + & - & + & - & + \\
\hline Inositol & - & - & - & + & - & - \\
\hline Mannitol & + & - & - & + & - & + \\
\hline Methyl $\alpha$-D-mannoside & - & - & - & + & - & - \\
\hline Methyl $\alpha$-D-glucoside & - & - & + & + & + & - \\
\hline$N$-Acetylglucosamine & - & - & + & + & + & + \\
\hline Amygdalin & - & - & + & + & - & - \\
\hline Arbutin & - & - & + & + & + & - \\
\hline Melibiose & + & + & $+^{*}$ & + & $+^{*}$ & + \\
\hline Trehalose & + & + & + & + & + & - \\
\hline Inulin & - & - & - & + & - & + \\
\hline D-Raffinose & + & + & + & + & $+^{*}$ & + \\
\hline Starch & - & - & + & + & + & + \\
\hline Glycogen & + & - & + & + & + & + \\
\hline D-Lyxose & + & - & - & - & - & - \\
\hline L-Fucose & + & + & - & + & - & - \\
\hline Gluconate & - & - & + & + & + & - \\
\hline $\begin{array}{l}\text { DNA G }+ \text { C content } \\
(\mathrm{mol} \%) \ddagger\end{array}$ & $50 \cdot 0$ & $50 \cdot 8^{a}$ & $50-52^{b}$ & $50 \cdot 5^{c}$ & $50-52^{b}$ & $50 \cdot 7^{d}$ \\
\hline
\end{tabular}

${ }^{\star}$ Results differ from those in the study of Kanzawa et al. (1995). $\dagger$ Results differ from those in the study of Rivas et al. (2005). $\ddagger$ Data from other studies are indicated as follows: $a$, Šmerda et al. (2005); b, Shida et al. (1997); c, Dasman et al. (2002); d, Rivas et al. (2005).

Paenibacillus (Shida et al., 1997). The fatty acid profile of the isolate is similar to those of the related reference strains (Table 2). It was possible to differentiate the novel strain from its closest phylogenetic neighbour, P. mendelii CCM $4839^{\mathrm{T}}$ on the basis of the considerably smaller amounts of $\mathrm{C}_{15: 0}(2 \cdot 3 \%)$, iso- $\mathrm{C}_{15: 0}(5 \cdot 0 \%)$ and iso- $\mathrm{C}_{17: 0}(1 \cdot 8 \%)$ in strain CCM $7311^{\mathrm{T}}$ or by the absence of $\mathrm{C}_{16: 1} \omega 11 \mathrm{c}$. In comparison with other paenibacilli, strain CCM $7311^{\mathrm{T}}$
Table 2. Fatty acid compositions (\%) of strain CCM $7311^{\top}$ and type strains of closely related Paenibacillus species

Fatty acids present in amounts less than $1.5 \%$ are omitted. Strains: 1, strain CCM $7311^{\mathrm{T}}$; 2, P. mendelii CCM $4839^{\mathrm{T}}$; 3, P. curdlanolyticus CCM $4536^{\mathrm{T}}$; 4, P. glycanilyticus JCM $11221^{\mathrm{T}}$; 5, P. kobensis CCM $4537^{\mathrm{T}} ; 6$, P. phyllosphaerae CCM $7310^{\mathrm{T}}$. All data are from this study. ND, Not detected.

\begin{tabular}{|lrrrrrr|}
\hline Fatty acid & $\mathbf{1}$ & $\mathbf{2}$ & $\mathbf{3}$ & $\mathbf{4}$ & $\mathbf{5}$ & $\mathbf{6}$ \\
\hline Saturated fatty acids & & & & & & \\
$\mathrm{C}_{14: 0}$ & $1 \cdot 8$ & $1 \cdot 2$ & $1 \cdot 5$ & $2 \cdot 0$ & $1 \cdot 4$ & $1 \cdot 8$ \\
$\mathrm{C}_{15: 0}$ & $2 \cdot 3$ & $6 \cdot 1$ & $2 \cdot 4$ & $0 \cdot 9$ & $3 \cdot 3$ & $5 \cdot 8$ \\
$\mathrm{C}_{16: 0}$ & $6 \cdot 3$ & $5 \cdot 9$ & $6 \cdot 4$ & $8 \cdot 9$ & $9 \cdot 9$ & $12 \cdot 2$ \\
$\mathrm{C}_{17: 0}$ & $0 \cdot 3$ & $1 \cdot 0$ & $0 \cdot 3$ & $\mathrm{ND}$ & $0 \cdot 6$ & $0 \cdot 8$ \\
iso-C $14: 0$ & $1 \cdot 4$ & $1 \cdot 3$ & $6 \cdot 0$ & $4 \cdot 3$ & $0 \cdot 6$ & $1 \cdot 9$ \\
iso-C $15: 0$ & $5 \cdot 0$ & $13 \cdot 5$ & $4 \cdot 7$ & $1 \cdot 5$ & $3 \cdot 5$ & $5 \cdot 1$ \\
iso-C $16: 0$ & $13 \cdot 7$ & $11 \cdot 4$ & $23 \cdot 9$ & $34 \cdot 9$ & $13 \cdot 5$ & $11 \cdot 1$ \\
iso-C $\mathrm{C}_{17: 0}$ & $1 \cdot 8$ & $6 \cdot 1$ & $1 \cdot 7$ & $0 \cdot 6$ & $1 \cdot 3$ & $1 \cdot 6$ \\
anteiso-C $15: 0$ & $59 \cdot 3$ & $45 \cdot 6$ & $47 \cdot 4$ & $43 \cdot 3$ & $58 \cdot 0$ & $48 \cdot 4$ \\
anteiso-C & $6 \cdot 6$ & $7 \cdot 1$ & $3 \cdot 5$ & $3 \cdot 5$ & $7 \cdot 9$ & $6 \cdot 6$ \\
Other fatty acids & & & & & & \\
$\mathrm{C}_{16: 1} \omega 11 c$ & $\mathrm{ND}$ & $0 \cdot 8$ & $0 \cdot 2$ & $\mathrm{ND}$ & $\mathrm{ND}$ & $1 \cdot 6$ \\
$\mathrm{C}_{16: 1} \omega 7 c$ alcohol & $\mathrm{ND}$ & $\mathrm{ND}$ & $1 \cdot 1$ & $\mathrm{ND}$ & $\mathrm{ND}$ & $2 \cdot 0$ \\
\hline
\end{tabular}

differed, for example, by containing a larger proportion of anteiso- $\mathrm{C}_{15: 0}(59 \cdot 3 \%)$. Only Paenibacillus kobensis CCM $4537^{\mathrm{T}}$ had a comparable fatty acid pattern.

The peptidoglycan structure was determined by the Identification Service of the Deutsche Sammlung von Mikroorganismen und Zellkulturen (DSMZ, Braunschweig, Germany). The cell-wall peptidoglycan was of the A1 $\gamma$ type, containing meso-diaminopimelic acid as the diagnostic diamino acid. Analysis of the respiratory quinones was carried out by the DSMZ Identification Service and Dr Brian Tindall (DSMZ). MK-7 was the only menaquinone present in strain CCM $7311^{\mathrm{T}}$.

Genomic DNA was isolated from the bacterial culture as described by Lambert et al. (1998). To determine the G+C content, DNA was hydrolysed in $90 \%$ formic acid for $30 \mathrm{~min}$ at $140^{\circ} \mathrm{C}$ (Swarts et al., 1996). The hydrolysed DNA was analysed by HPLC using a Finnigan AQA mass spectrometer (ThermoQuest). The relative amounts were determined from the peak areas and coefficients of relative molar absorption. The $\mathrm{G}+\mathrm{C}$ content was $50 \mathrm{~mol} \%$, in accordance with the overall content for members of the genus Paenibacillus (Shida et al., 1997).

DNA-DNA hybridization was performed according to Jahnke (1994), with the modifications of Šmerda et al. (2005). The levels of DNA-DNA hybridization for strain CCM $7311^{\mathrm{T}}$ with respect to $P$. mendelii CCM $4839^{\mathrm{T}}$, Paenibacillus phyllosphaerae CCM $7310^{\mathrm{T}}$, Paenibacillus curdlanolyticus CCM $4536^{\mathrm{T}}$, Paenibacillus glycanilyticus JCM $11221^{\mathrm{T}}$ and P. kobensis CCM $4537^{\mathrm{T}}$ were $16,15,20,24$ and $27 \%$, respectively. According to Wayne et al. (1987), these levels of 


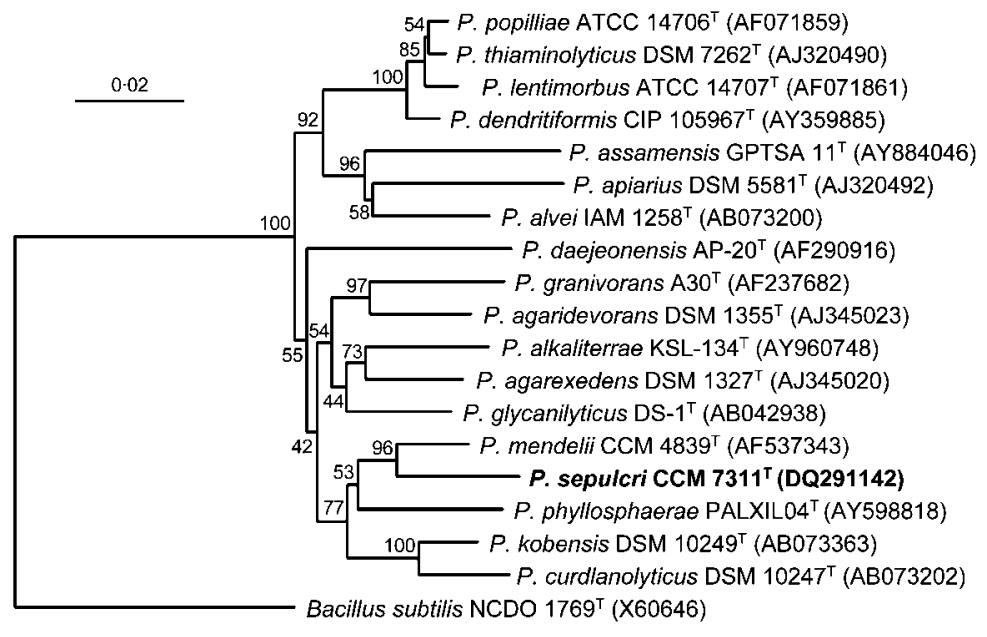

Fig. 1. Neighbour-joining phylogenetic tree, based on almost-complete 16S rRNA gene sequences, showing the position of strain CCM $7311^{\top}$ within the genus Paenibacillus. The significance of each branch is indicated by a bootstrap percentage calculated from 2000 resamplings. Bar, 0.02 nucleotide substitutions per site. An extended version of this tree is available as Supplementary Fig. S1 in IJSEM Online.

DNA-DNA relatedness $(\leqslant 70 \%)$ support the view that strain CCM $7311^{\mathrm{T}}$ is genomically distinct from these other species.

Amplification and sequencing of the 16S rRNA gene were performed as described by Šmerda et al. (2005). The resultant $16 \mathrm{~S}$ rRNA gene sequence was aligned with reference sequences obtained from GenBank with the CLUSTAL_X 1.8 multiple alignment program (Thompson et al., 1997). Evolutionary distance matrices were calculated using the algorithm of Jukes \& Cantor (1969). The phylogenetic tree was constructed with the neighbour-joining method (Saitou \& Nei, 1987) using the software package TREECON for Windows (Van de Peer \& De Wachter, 1994). The stability of the relationships was assessed statistically by performing a bootstrap analysis based on 1000 resamplings (Felsenstein, 1985).

The phylogenetic position of the 16S rRNA gene sequence of the strain is shown in the dendrogram (Fig. 1; see also Supplementary Fig. S1 available in IJSEM Online). The closest phylogenetic neighbours of the strain CCM $7311^{\mathrm{T}}$ are P. mendelii CCM $4839^{\mathrm{T}}$, P. phyllosphaerae CCM $7310^{\mathrm{T}}, P$. curdlanolyticus CCM $4536^{\mathrm{T}}$ and $P$. kobensis CCM $4537^{\mathrm{T}}$. The binary similarity values of strain CCM $7311^{\mathrm{T}}$ and the related species ranged between $96 \cdot 7 \%$ ( $P$. mendelii CCM $4839^{\mathrm{T}}$ ) and $93.5 \%\left(P\right.$. glycanilyticus JCM $\left.11221^{\mathrm{T}}\right)$. According to Stackebrandt \& Goebel (1994), these levels of 16S rRNA gene similarity $(\leqslant 97 \%)$ indicate that strain CCM $7311^{\mathrm{T}}$ is genomically distinct from these other species.

On the basis of the phenotypic, chemotaxonomic and genotypic results presented above, we consider that strain CCM $7311^{\mathrm{T}}$ represents a novel species of the genus Paenibacillus, for which we propose the name Paenibacillus sepulcri sp. nov.

\section{Description of Paenibacillus sepulcri sp. nov.}

Paenibacillus sepulcri (se.pul'cri. L. gen. neut. n. sepulcri from a tomb, pertaining to the place of isolation of the type strain).
Cells are Gram-variable, facultatively anaerobic rods. Spores are oval and are positioned subterminally in swollen sporangia. Moderately psychrotolerant. The temperature range for growth is $10-30{ }^{\circ} \mathrm{C}$, but no growth occurs at $37^{\circ} \mathrm{C}$; the optimum is $25^{\circ} \mathrm{C}$. Grows at $\mathrm{pH} 6 \cdot 0-8 \cdot 0$; the optimum is between $\mathrm{pH} 7 \cdot 2$ and $7 \cdot 4$. Tolerates up to $2 \% \mathrm{NaCl}$, but not $3 \% \mathrm{NaCl}$. Colonies on nutrient agar are circular, smooth, slightly convex with complete edges and colourless. Tests positive for catalase, oxidase, lecithinase and $\beta$-galactosidase and tests negative for arginine dihydrolase, DNase, haemolysis and citrate utilization. Hydrolyses aesculin and hippurate but not casein, starch, urea, gelatin, Tween 80 or tyrosine. Acid is produced from $\mathrm{D}$-arabinose, $\mathrm{L}$-arabinose, D-xylose, methyl $\beta$-D-xyloside, galactose, D-glucose, D-mannose, rhamnose, mannitol, salicin, cellobiose, maltose, lactose, melibiose, sucrose, trehalose, melezitose, D-raffinose, glycogen, $\beta$-gentiobiose, D-turanose, L-fucose and 5-ketogluconate, but not from glycerol, erythritol, ribose, L-xylose, adonitol, D-fructose, L-sorbose, dulcitol, inositol, sorbitol, methyl $\alpha$-D-mannoside, methyl $\alpha$-D-glucoside, $N$-acetylglucosamine, amygdalin, arbutin, inulin, starch, xylitol, D-tagatose, D-fucose, D-arabitol, L-arabitol, gluconate or 2-ketogluconate. Does not reduce nitrate to nitrite and is negative for the production of acetoin and indole. Hydrolysis of agar is not observed. The DNA G+C content is $50 \mathrm{~mol} \%$. The major fatty acid is anteiso- $\mathrm{C}_{15: 0}$. Cell-wall analysis reveals meso-diaminopimelic acid as the diagnostic diamino acid in the peptidoglycan. The predominant menaquinone is $\mathrm{MK}-7$.

The natural habitat is unknown. The type strain, CCM $7311^{\mathrm{T}}$ ( = LMG $19508^{\mathrm{T}}$ ), was isolated from biodeteriorated mural paintings in the Servilia tomb at the Roman necropolis of Carmona in Seville, Spain.

\section{Acknowledgements}

We thank Professor Dr Hans G. Trüper for help with the Latin construction of the novel species name. This study was supported by the long-term research programme MSM 0021622416 and LC 06073 of the Ministry of Education of the Czech Republic. 


\section{References}

Ash, C., Priest, F. G. \& Collins, M. D. (1993). Molecular identification of rRNA group 3 bacilli (Ash, Farrow, Wallbanks and Collins) using a PCR probe test. Proposal for the creation of a new genus Paenibacillus. Antonie van Leeuwenhoek 64, 253-260.

Dasman, Kajiyama, S., Kawasaki, H., Yagi, M., Seki, T., Fukusaki, E. \& Kobayashi, A. (2002). Paenibacillus glycanilyticus sp. nov., a novel species that degrades heteropolysaccharide produced by the cyanobacterium Nostoc commune. Int J Syst Evol Microbiol 52, 1669-1674.

Felsenstein, J. (1985). Confidence limits on phylogenies: an approach using the bootstrap. Evolution 39, 783-791.

Gordon, R. E., Haynes, W. C. \& Pang, C. H.-N. (1973). The Genus Bacillus. Agriculture Handbook no. 427. Washington, DC: US Department of Agriculture.

Heyrman, J. \& Swings, J. (2001). 16S rDNA sequence analysis of bacterial isolates from biodeteriorated mural paintings in the Servilia tomb (necropolis of Carmona, Seville, Spain). Syst Appl Microbiol 24, 417-422.

Jahnke, K.-D. (1994). A modified method of quantitative colorimetric DNA-DNA hybridization on membrane filters for bacterial identification. J Microbiol Methods 20, 273-288.

Jukes, T. H. \& Cantor, C. R. (1969). Evolution of protein molecules. In Mammalian Protein Metabolism, pp. 21-132. Edited by H. N. Munro. New York: Academic Press.

Kanzawa, Y., Harada, A., Takeuchi, M., Yokota, A. \& Harada, T. (1995). Bacillus curdlanolyticus sp. nov. and Bacillus kobensis sp. nov., which hydrolyse resistant curdlan. Int J Syst Bacteriol 45, 515-521.

Lambert, L. H., Cox, T., Mitchell, K., Rosselló-Mora, R. A., Del Cueto, C., Dodge, D. E., Orkand, P. \& Cano, R. J. (1998). Staphylococcus succinus sp. nov., isolated from Dominican amber. Int J Syst Bacteriol 48, 511-518.

MIDI (2001). Sherlock Microbial Identification System Operating Manual, version 4.0. Newark, DE: MIDI, Inc.

Páčová, Z. \& Kocur, M. (1984). New medium for detection of esterase and gelatinase activity. Zentralbl Bakteriol Mikrobiol Hyg A 258, 69-73.
Rivas, R., Mateos, P. F., Martínez-Molina, E. \& Velázquez, E. (2005). Paenibacillus phyllosphaerae sp. nov., a xylanolytic bacterium isolated from the phyllosphere of Phoenix dactylifera. Int J Syst Evol Microbiol 55, 743-746.

Saitou, N. \& Nei, M. (1987). The neighbor-joining method: a new method for reconstructing phylogenetic trees. Mol Biol Evol 4, 406-425.

Shida, O., Takagi, H., Kadowaki, K., Nakamura, L. K. \& Komagata, K. (1997). Transfer of Bacillus alginolyticus, Bacillus chondroitinus, Bacillus curdlanolyticus, Bacillus glucanolyticus, Bacillus kobensis and Bacillus thiaminolyticus to the genus Paenibacillus and emended description of the genus Paenibacillus. Int J Syst Bacteriol 47, 289-298.

Šmerda, J., Sedláček, I., Páčová, Z., Durnová, E., Smíšková, A. \& Havel, L. (2005). Paenibacillus mendelii sp. nov., a bacterium from surface-sterilized seeds of Pisum sativum L. Int J Syst Evol Microbiol 55, 2351-2354.

Stackebrandt, E. \& Goebel, B. M. (1994). Taxonomic note: a place for DNA-DNA reassociation and 16S rRNA sequence analysis in the present species definition in bacteriology. Int J Syst Bacteriol 44, 846-849.

Swarts, S. G., Smith, G. S., Miao, L. \& Wheeler, K. T. (1996). Effects of formic acid hydrolysis on the quantitative analysis of radiationinduced DNA base damage products assayed by gas chromatography/ mass spectrometry. Radiat Environ Biophys 35, 41-53.

Thompson, J. D., Gibson, T. J., Plewniak, F., Jeanmougin, F. \& Higgins, D. G. (1997). The CLUSTAL_X windows interface: flexible strategies for multiple sequence alignment aided by quality analysis tools. Nucleic Acids Res 25, 4876-4882.

Van de Peer, Y. \& De Wachter, R. (1994). TREECON for Windows: a software package for the construction and drawing of evolutionary trees for the Microsoft Windows environment. Comput Appl Biosci 10, 569-570.

Wayne, L. G., Brenner, D. J., Colwell, R. R. \& 9 other authors (1987). International Committee on Systematic Bacteriology. Report of the ad hoc committee on reconciliation of approaches to bacterial systematics. Int J Syst Bacteriol 37, 463-464. 